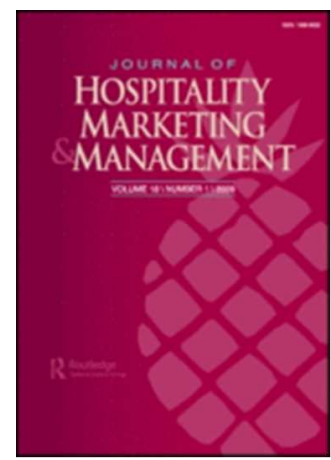

\title{
Organizational Culture and Customer Relationship Management: A Simple Linear Regression Analysis
}

\begin{tabular}{|r|l|}
\hline Journal: & Journal of Hospitality Marketing \& Management \\
\hline Manuscript ID & WHMM-06-2016-0748.R2 \\
\hline Manuscript Type: & Research Notes \\
\hline Abstract: & $\begin{array}{l}\text { Customer Relationship Management, Organizational Culture, Hotel } \\
\text { industry, Hospitality }\end{array}$ \\
& $\begin{array}{l}\text { Current study tries to investigate the combine effect of organizational } \\
\text { culture factors on implementing Customer Relationship Management (CRM) } \\
\text { in hotels. A questionnaire was administered among managers of a chain } \\
\text { hotel in the UK and collected data was subjected to correlation and simple } \\
\text { liner regression analysis. The results showed that creating cross functional } \\
\text { adaptive and responsive attitudes towards change, information sharing, } \\
\text { learning orientation and knowledge management, defined set of mission } \\
\text { and visions and high degree of innovation are the main predictors for a } \\
\text { successful CRM projects. }\end{array}$ \\
\hline \multicolumn{2}{|l}{} \\
\hline
\end{tabular}




\title{
Organizational Culture and Customer Relationship Management:
} A Simple Linear Regression Analysis

\begin{abstract}
Current study tries to investigate the combine effect of organizational culture factors on implementing Customer Relationship Management (CRM) in hotels. A questionnaire was administered among managers of a chain hotel in the UK and collected data was subjected to correlation and simple liner regression analysis. The results showed that creating cross functional teams, having culture of teamwork, committed and involved employees, adaptive and responsive attitudes towards change, information sharing, learning orientation and knowledge management, defined set of mission and visions and high degree of innovation are the main predictors for a successful CRM projects.
\end{abstract}

Keyword: Customer Relationship Management, Organizational Culture, Hotel industry

\section{Introduction}

Hotel managers around the world are under pressure to increase the profitability with limited resources and under intensifying competition (Daghfous and Barkhi, 2009). Customer Relationship Management (CRM) has been proven to be a key strategy for improving customer satisfaction, retention and profitability in the hotel businesses (Lo et al., 2010). Although CRM projects have strong influence on business performance in the acquisition, critics point to their high failure rates. Frow et al. (2011) in their study mentioned that 22 percent of CRM initiatives have a disappointing result (Economist Intelligence Unit, 2007) while AMR Research (2002) identifies that 20 percent of CRM initiatives damage customer relationships. Later AMR Research (2007) concludes that one in every three CRM deployments fails and fewer than 50 per cent of CRM projects fully meet expectations.

Different arguments have been put forward to identify the failure factors of CRM projects (Frow et al., 2011). It has been proven that CRM failure cannot be attributed to any one factor instead there are some common reasons for the poor results of CRM initiatives (Grabner-Kraeuter et al., 2007; Payne and Frow, 2006; Kale, 2004; Day, 2000). Initially, researchers investigating reasons for the failure of CRM focused on tactical issues, including quality of data (Abbott et al., 2001), project management skills (Ebner et al., 2002) and technological skills (Croteau and Li, 2003). However, more recently, researchers have considered strategic and organizational aspects of CRM implementation (Kim and Kim, 2008; Dimitriadis and Stevens, 2008; Rahimi and Gunlu, 2016). Among different organizational factors organizational culture has been identified by different researchers as one of the most important factor that enables or disables the achievement of desirable CRM outcomes (Buttle, 2004; Curry and Kkolou, 2004; Iriana and Buttle, 2006; Kale, 2004; Siriprasoetsin et al., 2011; Rahimi and Gunlu, 2016; Rahimi, 2017). 
Investigating organizational culture impacts on CRM projects has been at the centre of attention by different researchers. Organizational culture is the combination of shared assumptions, values, and beliefs which work together to dictate how the company perform and implement its strategies. Previous studied with empirical approaches tried to investigate the relationship between a limited set of organizational culture factors and CRM implementations (Siriprasoetsin et al., 2011; Iriana and Buttle, 2006; Rahimi and Gunlu, 2016). Rahimi and Gunlu (2016) in their study investigated the impact of fours organizational culture factors of adaptability, consistency, staff involvement and mission on implementing CRM in the hotel industry. In another study by Rahimi (2017) the impacts of organizational cultural factors on the three components of CRM (people, process and technology) has been investigated. While previous studies tried to investigate the impacts of a set of organizational culture factors on CRM implementation this is the first study that tries to investigating the combine effect of organizational culture factors on CRM implementation in the context of the hotel industry. The findings are beneficial for both academics and practitioners.

\section{Literature Review}

The key factors of success for hotel industries are not only the quality of the product or service offered, but also that of customer relationships (Olsen and Connolly, 2000). CRM solutions in hotel business aim to seek, gather and store the right guests' information towards; identifying and retaining the most profitable customers and improving the profitability of less profitable customers, and develop the quality of the services by customizing them (Sigala and Connolly, 2004; Rahimi and Kozak, 2016). In this study CRM is considered as a customeroriented culture by which a strategy is created for acquiring, enhancing the profitability and retaining customers, that is enabled by an IT application; for achieving mutual benefits for both the organization and the customers (Rababah et al., 2010:223).

Rahimi and Gunlu (20116) in their study mentioned that organizational culture is one of the crucial factors for successful CRM implementation in hotel businesses. Different studies have attempted to find organizational culture factors with potential impacts on CRM implementations. Galbreath and Rogers (1999) in their study found that defined set of mission and vision of the CRM strategy between all personnel and departments; move decision making processes down to all employees and front-line empowerment; motivating and involving employees; creating a learning environment and innovative atmosphere are essential to fill in the existing gap between CRM vision and its reality are essential to fill in the existing gap between CRM vision and its reality. Further Chen and Popovich (2003) in their study identified a set of organizational culture factors as predictors of a successful CRM program such as; having a customer centric culture; staff commitment and involvement and having a clear set of mission and vision about CRM goals. Rahimi and Gunlu (2016) in their study found that consistency and adaptability of the culture and sharing mission and vison of the company with the staff are critical organizational culture factors for successful CRM outcomes in hotels. Rahimi (2017) in her study found that organizational culture factors have a positive and significant impact on the three components of CRM. CRM implementation needs change in attitudes and processes hence organizational culture changes are required to 
encourage personnel to accept these changes (Mendoza et al., 2006). Alduwailah and Maged (2013) in their study mentioned that cultural aspects are the most important factor in success or failure of CRM and implementation will not succeed unless a proper cultural foundation exists.

As mentioned earlier different studies tried to identify organizational culture factors that have potential impacts on CRM implementation. According to Rahimi and Gunlu (2016) and Rahimi (2017) following organizational culture factors are the main predictors of a successful CRM implementation: cross functional teams, culture of teamwork, committed and involved employees, adaptive and responsive attitudes towards change, information sharing, learning orientation and knowledge management, defined set of mission and visions, higher degree of innovation. Considering the critical role of organizational culture in hotel industry and current research tries to empirically investigate the impact of organizational culture (as a composite of above mentioned factors) on implementing CRM. Accordingly the below conceptual framework and hypothesis were proposed.

Hypothesis: Organizational culture has a positive impact on CRM implementation of hotel.

\section{Figure 1}

\section{Methodology}

An overview of the previous literature regarding organizational culture and CRM shows that identified organizational culture factors by Rahimi and Gunlu (2016) and Rahimi (2017) have overlaps with the organizational culture traits (consistency, adaptability, mission and involvement) defined by Denison organizational culture Model (Denison and Neala, 1996). Hence Denison organizational culture survey selected to measure the organizational culture variable of the study. Based on the review of the literature Mendoza model (Mendoza et al., 2006) with the ability to measuring the three components of CRM outcomes (people, process and technology) is selected for measuring the CRM variable of the study. The questionnaire consisted of 86 questions and designed based on a 5-point Likert scale with an agree/disagree continuum. The first 60 questions were related to organisational culture and following 26 questions belong to CRM implementation. Last 6 questions were related to demographic details of respondents.

A chain hotel from the UK was selected as the case of the research. The total population was 364 managers of all branches. The respondents had different managerial positions, including operations, front and back office, human resources, sales, food and beverage, duty, finance, conference and banqueting, housekeeping and general management. In total 235 completed questionnaires returned back. Partly completed questionnaires were disregarded and 214 questionnaires were used for the statistical analysis of the study. Collected data was subjected to correlation and simple liner regression analysis by using Statistical Package for the Social Sciences (SPSS) version 20. Cronbach's alpha test was conducted to check the reliability of the questionnaire. The total alpha coefficient of the 
questionnaire was $0.95(\mathrm{p}<.001)$ and alpha coefficients for all items were $\leq 0.70(\mathrm{p}<.001)$ which are in the acceptable range $(\leq 0.70)$ suggested by Nunnaly (1978). The internal consistency of the items also calculated. Careful examination of item-total correlations shown all correlations range from 0.33 to 0.78 , which are above 0.32 levels suggested by Saxe and Weitz (1982).

\section{Results}

Demographic analysis showed that both male and female were equally distributed (53\% female and $47 \%$ Male). More than $40 \%$ of the respondents were between the ages of 30 and 39. $30 \%$ of the respondents had undergraduate degrees and $30 \%$ of the respondents were post graduate. Composite score for both variables is calculated by averaging representing items on the questionnaire. Organizational culture variable is calculated by averaging 60 responding items and CRM variable is calculated by averaging 26 its responding items. First correlation analyses were used to examine the relationship between two research variables. The results suggested that two variables are positively correlated and correlations were significant and equal to $+.74 \mathrm{p}<.001$ two-tailed. Toward testing the hypothesis and finding whether organizational culture (independent factor) is the predictors of CRM implementation (dependent variable) simple liner regression analysis is conducted. Regression analysis first confirmed by testing the assumptions of normality, linearity, homoscedasticity, and independence of residuals, revealing that the residuals are normally distributed (Tabachnick and Fidell, 1996). According to F-value $=60.346$ with sig $<.05$ of the regression test it can be said that the model has a good fit for the data. Both results showed that there is a positive and significant relationship between organizational cultures and CRM implementation hence proposed hypothesis is accepted.

\section{Discussion}

Current study tried to investigate the combine effect of organizational cultures factors on CRM implementation in the context of hotel industry. The correlation and regression analysis demonstrated that organizational culture has a positive and significant impact on CRM implementation in hotels. The results revealed that to achieve desired CRM outcomes general managers need to involve employees from different levels to set up cross functional teams. Teamwork should be fostered in the organization to create a work culture that values collaborations. All employees should be involved and engaged in the CRM project based on two way commitment and communication which not only enhance achieving CRM goals but also contributing to organisational and individual performance, productivity and well-being. CRM implementation needs change in attitudes and processes hence adaptive and responsive attitudes towards change is required and this needs to be done by focusing on individuals' emotions and personality traits. There need to be an effective communication in about CRM initiatives by sharing information. This helps to establish clear expectations for employees, enhance their involvement and lead to new ideas and innovation. Learning orientation and knowledge management approach should also be applied and serves as a manager's framework for improving the organization's learning potential. By guiding managerial 
intervention into the organization's knowledge base, knowledge management serves as a management tool and one of the most critical resources for CRM success. Defined set of mission and visions and high degree of innovation are also critical for successful CRM outcomes.

\section{Limitations}

The finding of this study is based on the composite impact of organizational culture and CRM and as Rahimi and Gunlu (2016) and Rahimi (2017) mentioned the detailed impact of each organizational culture factor on CRM implementation might be different. Although organizational culture factors is one of the crucial factors for implementing CRM there are other organizational factors that should be considered. This research is conducted in the context of hotel industry and the result might be different for other industries. Due to the limitation in access to all employees, only managers were selected as the sample of the study and future studies with all staff may shows different results.

\section{References}

Abbott, J., Stone, M. and Buttle, F. (2001), "Customer relationship management in practice a qualitative study”, Journal of Database Management, Vol. 9 No. 1, pp. 24-34.

Alduwailah, F and Maged, A. (2013), the Effect of Organizational Culture on CRM Success. European, Mediterranean and Middle Eastern Conference on Information Systems, pp.1-12.

AMR Research (2002), “The CRM application spending report, 2002-2004”, available at: www.amrreserach.com/Content/view.asp?pmillid $1 / 410494 \&$ docid $^{1} / 49398$ (accessed4 April 2009).

AMR Research (2007), "Ending CRM failures: get in theloop", available at: http://www.amrresearch.com/Content/View.aspx?pmillid1/420784 (accessed 6 October 2009).

Buttle, F. (2004), Customer Relationship Management: Concepts and Tools, Elsevier Oxford.

Chen, I., and Popovich, K. (2003), "Understanding Customer Relationship Management (CRM): People, Process and Technology", Business Process Management Journal, Vol.9No.5, pp. 672-688.

Croteau, A. and Li, P. (2003), "Critical success factors of CRM technological initiatives", Canadian Journal of Administrative Sciences, Vol. 20 No. 1, pp. 21-34.

Curry, A., and Kkolou, E. (2004). "Evaluating CRM To Contribute To TQM Đmprovement A Cross Case Comparison", The TQM Magazine, Vol.16 No.5, pp. 314-324.

Daghfous, A., \& Barkhi, R. (2009). The strategic management of information technology in UAE hotels: An exploratory study of TQM, SCM, and CRM implementations. Technovation, 29(9), 588-595. 
Day, G. (2000), Capabilities for Forging Customer Relationships,Report No. 00-118, Marketing Science Institute,Cambridge, MA.

Denison, D.R, and Neale, W. (1996), Denison Organizational Culture Survey. Aviat: AnnArbor, MI.

Dimitriadis, S. and Stevens, E. (2008), “Integrated customer relationship management for service activities: an internal/ external gap model", Managing Service Quality, Vol. 18 No. 5, pp. 496-511.

Ebner, M., Hu, A., Levitt, D. and McCrory, J. (2002), "How to rescue CRM”, The McKinsey Quarterly, No. 48.

Economist Intelligence Unit (2007), "Improving customer relationships: an integrated approach", available at: http:// graphics.eiu.com/upload /SAP_CRM.pdf (accessed 6 October 2009).

Frow, P., Payne, A., Wilkinson, I. F., \& Young, L. (2011). Customer management and CRM: addressing the dark side. Journal of Services Marketing, 25(2), 79-89.

Galbreath, J., and Rogers, T. (1999). Customer relationship leadership: a leadership and motivation model for the twenty-first century business. The TQM magazine, 11(3), 161-171.

Grabner-Kraeuter, S., Moedritscher, G., Waiguny, M. and Mussnig, W. (2007), "Performance monitoring of CRM initiatives", 40th Annual Hawaii International Conference on System Sciences, Hawaii.

Iriana, R., and Buttle, F. (2006). Customer relationship management (CRM) system implementations: An assessment of organisational culture.

Kale, S. (2004), "CRM failure and the seven deadly sins", Marketing Management Journal, Vol.13 No.5, pp. $42-46$.

Kim, H. and Kim, Y. (2008), "A CRM performance measurement framework: its development process and application”, Industrial Marketing Management, Vol. 38, pp. 47789.

Lo, A., Stalcup, L., and Lee, A. (2010), "Customer Relationship Management for hotels in Hong Kong", International Journal of Contemporary Hospitality Management, Vol.22 No.2, pp. 139-159.

Mendoza, L., Marius, A., Perez, M., and Griman. (2006), "Critical Success Factors for a Customer Relationship Management strategy", Information and Software Technology, Vol, 49 No.8, pp. 913-945.

Nunnally J C (1978) Psychometric Theory New York: McGraw-Hill.

Olsen, M.D., Connolly, D.J., 2000, February. Experience-based travel. How technology is changing the hospitality industry. Cornell Hotel and Restaurant Administration Quarterly, $30-40$. 
Payne, A. and Frow, P. (2006), "Customer relationship management: from strategy to implementation”, Journal of Marketing Management, Vol. 22 Nos 1-2, pp. 135-68.

Rababah, K., Mohd, H., andIbrahim, H. (2011), " Customer Relationship Management(CRM) Process from Theory to Practice: The Preimplementation Plan of CRM System" ,Internatonal Journal of e-Education, e-Business, e-management and e-learning, Vol.1 No.1, pp. 1.

Rahimi, R, and Gunlu, E. (2016). Implementing Customer Relationship Management (CRM) in hotel industry from organizational culture perspective. International Journal of Contemporary Hospitality Management. 28 (1). 89 - 112.

Rahimi, R, and Kozak, M. (2016): Impact of Customer Relationship Management on Customer Satisfaction: The Case of a Budget Hotel Chain, Journal of Travel \& Tourism Marketing, DOI: 10.1080/10548408.2015.1130108.

Rahimi, R. (Forthcoming, 2017). Customer Relationship Management (People, Process and Technology) and Organisational Culture in Hotels: Which traits matter?. International Journal of Contemporary Hospitality Management. 29 (5) . DOI: 10.1108/IJCHM-10-2015-0617.

Saxe R and Weitz B (1982) The SOCO scale: a measure of the customer orientation of salespeople .Journal of marketing research 343-351.

Sigala, M., and Connolly, D. (2004), In search of the next big thing: IT issues and trends facing the hospitality industry: A Review of the Sixth Annual Pan-European Hospitality Technology Exhibition and Conference (EURHOTEC; International Hotel and Restaurant Association, 19-21 February 2001. Paris, France: Palais Des Congres. . Tourism Management, Vol.25 No.6, pp. 807-809.

Siriprasoetsin, P., Tuamsuk, K., and Vongprasert, C. (2011), "Factors affecting customer relationship management practices in Thai academic libraries", The International Information and Library Review, Vol.43 Vol.4, pp. 221-229.

Tabachnick, B. G., and L. S. Fidell. (1996). Using multivariate statistics. HarperCollins, New York, New York, USA.

Verhoef, P. C. and Langerak, J. (2003), "Understanding the effect of customer relationship management efforts on customer retention and customer share development ", Journal of Marketing, Vol.67, pp.30-45. 
Figure 1: Conceptual Framework of Research

\section{Organizational Culture}

\section{CRM Implementation}

Combine impact of

- Cross functional teams;

- Culture of teamwork; Committed and involved employees;

- Adaptive and responsive attitudes towards change; Information sharing;

- Learning orientation and knowledge management;

- Defined set of mission and visions;

- Higher degree of innovation 